\title{
Systemy informacji przestrzennej - narzędzie partycypacyjnej polityki rozwoju lokalnego
}

\section{Istota lokalnej polityki rozwoju}

Politykę w ujęciu funkcjonalnym należy postrzegać, jako funkcję systemu społeczno-gospodarczego, którego rozwój możliwy jest dzięki: rozwiązywaniu konfliktów, podejmowaniu decyzji o podziale dóbr, agregacji i selekcji interesów poszczególnych osób lub grup społecznych, socjalizacji i komunikacji politycznej wewnątrz systemu, jak i poza nim (Sokół, Żmigrodzki, 1999, s. 231-232; Antoszewski, Herbut, 2003, s. 329-330). Tożsame podejście należy stosować w odniesieniu do polityki rozwoju lokalnego. Jak wskazuje Jastrzębska (2003, s. 5-6), jest to świadome, celowe i zorganizowane działanie samorządu oraz jego jednostek organizacyjnych polegające na wyznaczaniu celów służących społeczności lokalnej oraz doborze metod i instrumentów pozwalających realizować wyznaczone zamierzenia. Ponadto należy wskazać, że polityka rozwoju lokalnego jest sztuką rządzenia przy racjonalnym wykorzystaniu lokalnych zasobów.

Polityka w każdym ujęciu prowadzić ma do oddziaływania na różne jednostki (społeczne, gospodarcze, instytucje działające na terenie gminy itp.). Odziaływanie to jest swego rodzaju kierowaniem zachowaniami różnych podmiotów pomimo ich autonomii, która wynika chociażby z aktów prawnych czy Konstytucji RP. Intencją wpływania władz na aktorów lokalnych jest uzyskanie ich określonego zachowania, co pozwala na realizację założonych celów. Podstawą oddziaływania podmiotu polityki na uczestników z nią związanych są instrumenty polityki. Jako podstawowy instrument polityki autorzy wskazują plan, który może przyjmować

* Uniwersytet Łódzki, Wydział Ekonomiczno-Socjologiczny, Instytut Gospodarki Przestrzennej, Katedra Gospodarki Regionalnej i Środowiska, 90-214 Łódź, Rewolucji 1905 r. nr 39. 
postać planu struktury bądź planu operacyjnego (Regulski, Ptaszyńska, Kaźmierska, 1986; Regulski, Kocon, Ptaszyńska-Wołoczkowicz, 1988, s. 40). Podobne podejście do polityki prezentuje Tadeusz Markowski (1999, s. 28), który wskazuje, że polityka rozwoju lokalnego jest planowym działaniem zorientowanym na rozwój jednostki terytorialnej, prowadzonym przez organy samorządu terytorialnego oraz jednostki mu podległe, które dzięki instrumentom realizują cele zorientowane na rozwój społeczno-gospodarczy jednostki.

Podstawą dla prowadzenia polityki rozwoju lokalnego jest zrozumienie definicji samego rozwoju lokalnego. Wskazanie jednej kompleksowej definicji rozwoju lokalnego nie jest możliwe, ponieważ szerokie spektrum oddziaływania rozwoju lokalnego na różne sfery życia i funkcjonowania jednostki pozwala na rozbudowywanie definicji w zależności od podejścia autorów, badających zjawiska związane z rozwojem lokalnym. Rozwój lokalny ma prowadzić do pozytywnych zmian, obejmujących wzrost ilościowy i postęp jakościowy na obszarze działania wspólnoty lokalnej (Wojtasiewicz, 1997, s. 10). Co ważne, proces ten powinien odbywać się w oparciu o zaangażowanie lokalnych zasobów, które pozwalają budować markę danego terytorium (Blakely, 1989, s. 57-72).

Dbając o rozwój lokalny, władze kreują polityki lokalne i dzięki ich budowaniu mogą wpływać na określone obszary funkcjonowania jednostki samorządowej. Polityka rozwoju lokalnego może być powiązana z politykami rozwoju realizowanymi na szczeblu krajowym, poprzez potrzebę jej zgodności z aktami wyższego rzędu, co widoczne jest w przypadku polityki przestrzennej czy środowiskowej. Politykę rozwoju lokalnego należy uznać za politykę kompleksowego podejścia do jednostki terytorialnej, która swym zakresem powinna obejmować wszystkie obszary działalności aktorów lokalnych na danym terytorium. Często terytorium to utożsamiane jest $\mathrm{z}$ granicami administracyjnymi gminy, co jest dużym uproszczeniem, wynikającym z utrwalającej się w Polsce sytuacji, prowadzącej do zaniechań w zakresie współpracy samorządów lokalnych w obrębie polityk rozwoju. Stanowisko takie utrudnia działania w zakresie kreowania terytorialno-funkcjonalnego podejścia do rozwoju. Najczęściej władze lokalne promują swoją odrębność poprzez prowadzenie polityki rozwoju lokalnego w oderwaniu od otoczenia. Nie zawsze polityka rozwoju lokalnego kłóci się z polityką lokalną prowadzoną przez sąsiedni samorząd, jednak wciąż brakuje na tym polu współpracy.

Polityka rozwoju lokalnego prowadzona jest przez władze lokalne, które stają się ośrodkiem kierującym działaniami w zakresie podejmowanych polityk. Ośrodek ten zmierza do realizacji ustalonych celów, do czego wykorzystuje określone środki (Opałek, 1986, s. 236-239). Władze samorządowe podejmują suwerenne decyzje dzięki prawu stanowionemu na szczeblu krajowym. Realizacja decyzji władz możliwa jest dzięki wykorzystywaniu dostępnych narzędzi, które pozwalają na oddziaływanie na aktorów lokalnych oraz podejmowane przez nich działania. Podstawą dla realizacji działań musi być jednak świadomość przed- 
siębranych zadań, dostępnych kompetencji i instrumentarium. Prowadzić to musi do odpowiedzialnego stosowania narzędzi w zastanych warunkach oraz świadomości w zakresie efektów i skutków podejmowanych decyzji (Nowakowska, Przygodzki i Chądzyński, 2007, s. 197-200).

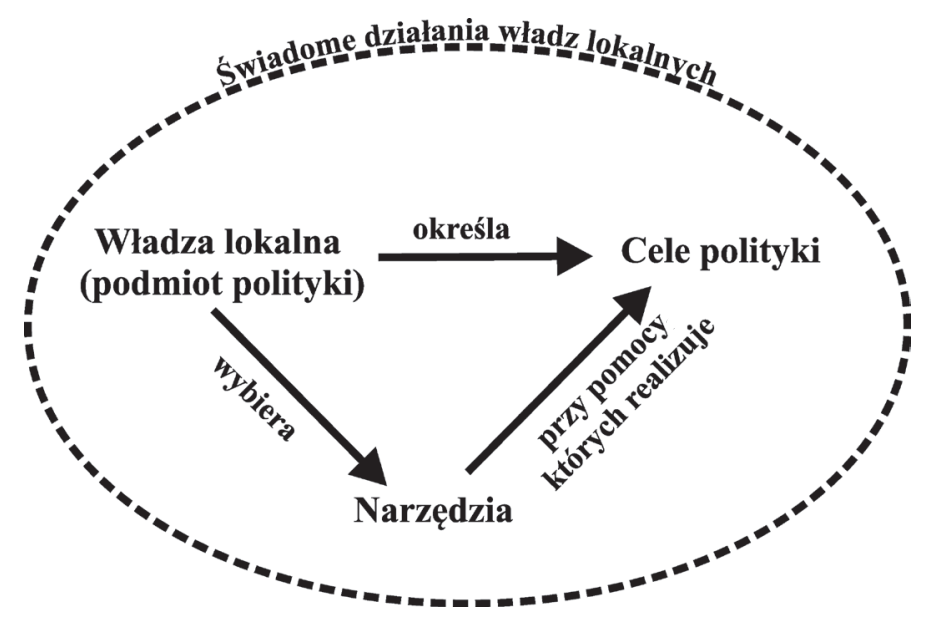

Rysunek 1. Definicja polityki

Źródło: opracowanie własne na podstawie: Opałek (1986) oraz Nowakowska, Przygodzki, Chądzyński (2007)

Polityka rozwoju lokalnego jest podstawą funkcjonowania każdej jednostki terytorialnej. Podejście to wynika $\mathrm{z}$ wdrażania wzorca rozproszonego ośrodka władzy, współdziałającego z aktorami lokalnymi, zaangażowanymi w działania mające przyczynić się do kształtowania tej polityki oraz podniesienia poziomu życia ludności (Rogers, 2006, s. 305). Współdziałanie może prowadzić bowiem do osiągania celów wyznaczonych przez władze lokalne, a dialog pomaga wybrać instrumenty i metody adekwatne do jego osiągania w zaistniałych warunkach. Jak wskazuje A. Nowakowska (2000, s. 14) działania te muszą prowadzić do osiągania celów w sposób szybki, charakteryzować się niskimi kosztami oraz być najbardziej zbliżone do wartości optymalnych założonych w oparciu o system wartości panujący w danej jednostce terytorialnej.

Niezależnie od przyjętych założeń polityka rozwoju lokalnego jest działaniem kompleksowym, na które składają się elementy złożone z polityk cząstkowych. Ważnym elementem oddziaływania jest fakt, że polityki cząstkowe dotyczą różnych obszarów rozwoju. Co za tym idzie, kierując się zapisami ustawy o samorządzie gminnym (art. 7, Dz. U. 1990, nr 16, poz. 95), można wskazać niezamknięty katalog polityk cząstkowych, którymi są: polityka przestrzenna, polityka infrastrukturalna, polityka ochrony zdrowia, polityka społeczna, polityka edukacyjna, 
polityka kulturowa, polityka porządku publicznego i bezpieczeństwa obywateli, polityka prorodzinna, polityka budżetowa, polityka finansowa czy polityka promocyjna. Zakres oddziaływania poszczególnych polityk zależy od specyfiki jednostek terytorialnych oraz od podejścia władz lokalnych. Wagę poszczególnych polityk określa bowiem ośrodek decyzyjny, który może wymuszać na osobach realizujących i monitorujących poszczególne strategie działania, stosowanie odpowiedniego podejścia i budowania zaangażowania w tym zakresie.

Realizacja poszczególnych polityk powiązana jest z istniejącymi uwarunkowaniami rozwoju. Uwarunkowania te są zróżnicowane i uzależnione od położenia gminy, otwartości władz lokalnych czy umiejętności menadżerskich włodarzy. Czynniki rozwoju są powiązane z lokalną jednostką terytorialną i są elementem oddziałującym na podejmowane przez władzę lokalną działania. Występowanie bądź nie poszczególnych czynników wpływa na realizowane polityki cząstkowe. Czynniki rozwoju lokalnego porządkowane są według różnych kryteriów, co widoczne jest w literaturze przedmiotu (Zalewski, 2000; Gorzelak, 2000; Swianiewicz, 2005; Noworól, 2007; Pokładecki, 2013). Należy podkreślić, że uwarunkowania endogeniczne, niezależnie od przyjętej klasyfikacji, dokonywane są w tej samej grupie czynników, które podlegają różnemu przyporządkowaniu. Jednym z wykorzystywanych podziałów jest zaproponowana przez Paryska (2001, s. 73-122) klasyfikacja, gdzie jako czynniki oddziałujące na rozwój lokalny oraz prowadzoną politykę wymienia on:

- potrzeby społeczności lokalnej,

- zasoby i walory środowiska,

- zasoby pracy,

- zainwestowanie infrastrukturalne,

- potencjał gospodarczy,

- rynek lokalny i rynki zewnętrzne,

- kapitał finansowy,

- poziom nauki i kultury,

- nowoczesne technologie,

- teren i korzyści miejsca,

- stosunki międzynarodowe i współpracę bilateralną.

Czynniki te przyczyniać się mogą do rozwoju jednostki poprzez ich uwzględnienie $\mathrm{w}$ politykach lokalnych na danym terytorium. W odniesieniu do niektórych czynników należy wziąć pod uwagę ich różnorodność oraz możliwość pozytywnego wpływania na inne czynniki, które w pierwszym odczuciu mogą wydawać się barierą rozwoju. Tak dzieje się chociażby w przypadku zasobów pracy, ponieważ nie zawsze wysoko wykwalifikowana siła robocza warunkuje rozwój terytorium. W niektórych przypadkach strategie przedsiębiorstw zakładają poszukiwania lokalizacji w przestrzeni, warunkując to znalezieniem siły roboczej szczebla podstawowego. Przykładem może być lokalizacja montowni Dell, Inde- 
sit, Bosch-Siemens w Łodzi czy lokalizacja fabryki General Motors w Gliwicach. Należy również wskazać, że w odniesieniu do potencjału gospodarczego rozwój nie może się opierać na monokulturach gospodarczych, wręcz przeciwnie, musi być wspomagany przez wielogałęziowy rozwój gospodarczy dostosowany do lokalnych warunków, co wymusza prowadzenie polityki rozwoju lokalnego otwartej na różnego rodzaju podmioty gospodarcze.

Należy podkreślić, że polityka rozwoju lokalnego powinna opierać się na wykorzystaniu kapitału inwestycyjnego aktorów lokalnych oraz przewidywać wykorzystanie kapitału zlokalizowanego w bliższym i dalszym otoczeniu. Przy tak postawionych założeniach należy wskazać, że inwestorami na terenie gminy są mieszkańcy, samorząd lokalny oraz podmioty gospodarcze. Środowisko lokalne może natomiast przyciągać inwestorów z zewnątrz w oparciu o prowadzenie polityki marketingowej, która staje się podstawą promocji samorządu lokalnego. Powiązanie wszystkich polityk cząstkowych pozwala na kompleksowe działania podejmowane na obszarze gminy i wskazywanie mocnych stron i szans, które mogą zachęcać potencjalnych inwestorów.

Istotnym uwarunkowaniem prowadzenia skutecznej i efektywnej polityki rozwoju lokalnego jest wykorzystanie nowych technologii przez podmioty gospodarcze lokalizowane na terenie gminy. Wpływa to również pozytywnie na wzrost efektywności ich działania oraz pozwala na poszerzenie rynków zbytu. Podobnie wykorzystanie tych technologii w sektorze administracji publicznej pozwala na skrócenie dystansu między władzami lokalnymi a aktorami. Może to również budować atrakcyjność jednostki terytorialnej zarówno wśród społeczności lokalnej, jak i w otoczeniu.

Kolejnym uwarunkowaniem wpływającym na prowadzoną politykę rozwoju jest współpraca międzynarodowa, która staje się czynnikiem pozwalającym na podnoszenie kompetencji kadr urzędniczych oraz buduje otwartość na nowe technologie poprzez poznanie możliwości ich wykorzystania. Ważnym elementem jest również możliwość rozbudowywania funkcjonalności i rozwijanie wykorzystania narzędzi, które już funkcjonują w urzędach. Podejście takie prowadzi do nawiązywania szerszych kontaktów i wzbogacania rozwiązań istniejących w polskich warunkach o nowe praktyczne zastosowania.

Uwarunkowaniem prowadzenia polityki rozwoju lokalnego, które niezbyt często wymienia się w literaturze przedmiotu, jest partycypacja społeczna oraz stan społeczeństwa obywatelskiego. Elementy te wskazuje się jako źródło budowania polityk lokalnych w zgodzie z ideą współrządzenia, co pozwala na minimalizację konfliktów społecznych poprzez ich rozwiązywanie w procesie kreowania polityk sektorowych gminy. Pozwala to również na integrowanie społeczności lokalnej w działaniach na rzecz rozwoju. Dzięki wzajemnej współpracy i komunikacji tworzą się korzystne warunki dla prowadzenia dialogu na rzecz rozwoju lokalnego (Hausner, 1999, s. 18-21; Potoczek, 2003, s. 53; Podedworna, 2013).

Ważnym elementem wpływającym na politykę rozwoju lokalnego jest otoczenie gminy oraz uwarunkowania wynikające z prawa krajowego. Jako otoczenie 
traktować należy przede wszystkim samorządy lokalne znajdujące się w bezpośrednim sąsiedztwie danej gminy. Podejście takie nabrało innego znaczenia w nowym okresie programowania Unii Europejskiej. Wynika to z założeń, że projekty finansowane ze środków UE nie będą musiały być związane z pojedynczą jednostką samorządu terytorialnego. Można pokusić się o stwierdzenie, że Unia Europejska dzięki Zintegrowanym Inwestycjom Terytorialnym (ZIT) przekracza granice administracyjne gmin i promuje współpracę między podstawowymi jednostkami podziału administracyjnego kraju. Według założeń narzędzie to zakłada wdrażanie międzysektorowych strategii rozwoju terytorialnego przy założeniu, że istnieje możliwość tworzenia opracowań transgranicznych, co zgodne jest z działaniami podejmowanymi w ramach europejskiej współpracy terytorialnej. Co ciekawe, podkreśla się, że elementem implementacji ZIT może być działanie oparte na rozwoju kierowanym przez społeczność lokalną. Narzędzie to wskazuje również na możliwość współpracy miast wojewódzkich z obszarami powiązanymi z rdzeniem. Ważnym elementem dla rozwoju ośrodków regionalnych i subregionalnych oraz powiązanych z nimi obszarów będzie możliwość podjęcia stosownych decyzji przez samorząd województwa, co pozwoli im na szersze korzystanie $\mathrm{z}$ dostępnych środków UE w okresie programowania 2014-2020. Takie podejście nakłania do myślenia o obszarach funkcjonalnych, jako terytorium wpływającym pozytywnie na rozwój lokalny, tak pojedynczych gmin, jak również pozostałych jednostek wchodzących w skład wyznaczonych obszarów. Co za tym idzie działania władz lokalnych w zakresie partnerstwa muszą mieć sformalizowany charakter w postaci stowarzyszeń czy związków międzygminnych. Takie działania staną się podstawą do wykorzystania środków z programów regionalnych.

Działania władz lokalnych w zakresie tworzenia polityki rozwoju lokalnego wymagają stosowania instrumentów określonych w definicji jako narzędzia. Należy przez nie rozumieć prawem określone sposoby, jakich ośrodek władzy może użyć do skłonienia aktorów lokalnych do dostosowania zachowań do realizowanych celów polityki (Needham, 1982, s. 3; Gajl, 1988, s. 15; Regulski, Kocon, Ptaszyńska-Wołoczkowicz, 1988, s. 44). Do instrumentarium wykorzystywanego w prowadzeniu polityki rozwoju lokalnego zalicza się: strategie rozwoju gmin, budżet gminy, wieloletnie prognozy finansowe, budżet obywatelski, fundusz sołecki, studium uwarunkowań i kierunków zagospodarowania przestrzennego, miejscowe plany zagospodarowania przestrzennego, program ochrony środowiska, systemy informacji o terenie, narzędzia wsparcia przedsiębiorczości lokalnej (np. kształtowanie stawek podatków lokalnych, wsparcie dla: agencji rozwoju regionalnego i lokalnego, centrów wspierania biznesu, ośrodków wspierania przedsiębiorczości, inkubatorów przedsiębiorczości, parków technologicznych czy funduszy poręczeniowo-kredytowych), plany rozwoju lokalnego, lokalne programy rewitalizacji czy partnerstwo publiczno-prywatne. Podstawowymi kryteriami oceny instrumentów są: szybkość działania instrumentu - rozumiana jako czas 
potrzebny do realizacji celu od momentu zastosowania instrumentu, zmienność - rozumiana po pierwsze jako możliwość zastosowania instrumentu do wielu niezależnych sytuacji, po drugie jako możliwość zmiany lub odwrócenia efektu po zastosowaniu narzędzia, trzecim elementem oceny jest zakres wywoływania efektów (skutków) (Markowski, 1999, s. 34-35).

Instrumenty można klasyfikować według różnych kryteriów. Najczęściej spotykanymi są klasyfikacje pozwalające dzielić instrumenty ze względu na obowiązek ich stosowania, dzięki czemu wyróżniamy narzędzia obligatoryjne (np. budżet gminy, wieloletnia prognoza finansowa, studium uwarunkowań i kierunków zagospodarowania przestrzennego, program ochrony środowiska) i fakultatywne (np. strategie rozwoju gmin, miejscowe plany zagospodarowania przestrzennego, narzędzia wsparcia przedsiębiorczości lokalnej, plan rozwoju lokalnego).

Innym kryterium jest zasięg oddziaływania instrumentu: indywidualny (np. decyzje o warunkach zabudowy, decyzje o wycięciu drzewa), lokalny (np. co do zasady miejscowe plany zagospodarowania przestrzennego, lokalny program rewitalizacji) i powszechny (np. budżet gminy, studium uwarunkowań i kierunków zagospodarowania przestrzennego). Instrumenty powszechne oddziałują na wszystkie podmioty, instrumenty lokalne dotyczą podmiotów funkcjonujących na wydzielonym obszarze jednostki terytorialnej, a instrumenty indywidualne skierowane są do konkretnego podmiotu (Markowski, 1999, s. 36).

Tabela 1. Systematyka instrumentów polityki przestrzennej

\begin{tabular}{|l|l|}
\hline \multicolumn{1}{|c|}{ Kryterium podziału } & \multicolumn{1}{c|}{ Klasyfikacja instrumentów } \\
\hline Oddziaływanie na zachowanie się jednostek & $\begin{array}{l}\text { bezpośrednie } \\
\text { pośrednie }\end{array}$ \\
\hline Zasięg oddziaływania & $\begin{array}{l}\text { powszechne } \\
\text { lokalne } \\
\text { indywidualne }\end{array}$ \\
\hline Źródło powstania instrumentu & $\begin{array}{l}\text { administracyjno-prawne } \\
\text { prawno-własnościowe } \\
\text { finansowe (ekonomiczne) } \\
\text { informacyjne } \\
\text { infrastrukturalne }\end{array}$ \\
\hline Obowiązek stosowania & $\begin{array}{l}\text { obligatoryjne } \\
\text { fakultatywne }\end{array}$ \\
\hline Sfera oddziaływania & $\begin{array}{l}\text { finansowe } \\
\text { pozafinansowe }\end{array}$ \\
\hline
\end{tabular}

Źródło: opracowanie własne z wykorzystaniem: Regulski, Ptaszyńska, Kaźmierska (1986, s. 18-24); Markowski (1999, s. 36); Jastrzębska (2003, s. 7-8); Kot (2003, s. 108); Wojciechowski (2003, s. 193-201); Skica (2008, s. 45); Feltynowski (2009a, s. 25). 
Klasyfikacja instrumentów może odbywać się w oparciu o przynależność narzędzi do grupy instrumentów finansowych i niefinansowych. Kryterium podziału może być oddziaływanie instrumentu na zachowanie się jednostek w przestrzeni, dzięki czemu wyróżnić można narzędzia bezpośrednie i pośrednie. Podobnie za wyznacznik podziału można uznać źródło powstania instrumentu. W tym przypadku wyróżnia się narzędzia: administracyjno-prawne, prawno-własnościowe, finansowe (ekonomiczne), informacyjne, planistyczne i infrastrukturalne (Regulski, Ptaszyńska, Kaźmierska, 1986, s. 18-24; Jastrzębska, 2003, s. 7-8; Kot, 2003, s. 108; Wojciechowski, 2003, s. 193-201; Skica, 2008, s. 45). Niezależnie od rodzaju klasyfikacji zastosowanej do grupowania narzędzi, ich ogólny zbiór pozostaje w każdej systematyce taki sam.

Pokreślić należy, że instrumenty polityki rozwoju lokalnego na obszarze gminy charakteryzują się funkcjami: regulacyjną, koordynacyjną, informacyjną, kontrolną i kreacyjną. Podejście takie pozwala na wskazywanie instrumentów polityki rozwoju lokalnego jako środka regulującego i koordynującego zachowanie aktorów lokalnych zgodnie z założonymi przez ośrodek decyzyjny celami. Każde działanie samorządu lokalnego niesie ze sobą czynnik informacyjny, podobnie uznać należy, że narzędzia polityki rozwoju lokalnego dostarczają informacji i wiedzy na temat jednostki lokalnej. Właśnie te informacje stają się również elementem pozwalającym na prowadzenie działań promocyjnych.

Nie bez znaczenia okazuje się funkcja kontrolna, która pozwala na kontrolę zarówno działań aktorów lokalnych, jak i władzy lokalnej, która kreuje politykę rozwoju lokalnego. Działania kontrolne pozwalają w łatwy sposób weryfikować zachowania aktorów lokalnych, w szczególności, gdy odbiegają one od założeń dokumentów tworzących ramy polityki rozwoju lokalnego. $Z$ drugiej strony działania podejmowane przez władze lokalne mogą być kontrolowane przez społeczność lokalną w zakresie zgodności z założonymi celami polityki rozwoju. Na znaczeniu zyskuje także funkcja kreacyjna, która wymusza działania pozwalające na znajdowanie nowych rozwiązań w zakresie stymulowania rozwoju gminy. Działania takie są możliwe dzięki współpracy władz lokalnych ze społecznością lokalną, ponieważ pozwala to na podnoszenie wartości celów, które zostały wypracowane przez ogół społeczności zamieszkującej gminę.

\section{Polityka rozwoju lokalnego w kontekście koncepcji dobrego rządzenia}

\subsection{Koncepcja good governance i jej zasady}

Koncepcja good governance swoje początki ma w działaniach podejmowanych przez Bank Światowy. Po raz pierwszy termin ten został wprowadzony w opracowaniu Banku Światowego dotyczącym Subsaharyjskiej Afryki, w któ- 
rym brak dobrego rządzenia został uznany za przyczynę braku postępów rozwojowych (World Bank, 1989, s. 3). Od początku lat 90. koncepcja good governance zaczęła być wdrażana w krajach rozwijających się w oparciu o idee skutecznego i efektywnego zarządzania. Było to możliwe dzięki prowadzonym przez Bank Światowy programom wsparcia. Działania miały podnosić poziom potencjału administracyjnego w celu lepszej absorpcji środków finansowych. Z czasem jednak good governance zaczął obejmować nowe obszary funkcjonowania państw (Rutkowski, 2009, s. 69). Koncepcja zaczęła być również wdrażana na szczeblach niższych niż krajowy, dzięki czemu można było dotrzeć do szerszej grupy odbiorców oraz podnosić efektywność działania administracji w regionach czy gminach.

Zgłębienie koncepcji dobrego rządzenia musi być związane ze zrozumieniem pojęcia governance, które przez ekspertów Banku Światowego określane jest jako proces wyboru, monitoringu i wymiany rządów, zdolność administracyjna do formułowania i implementowania polityk publicznych i zapewniania dobrej jakości usług publicznych oraz konieczność udziału obywateli w pracach instytucji administracyjnych, które zarządzają politykami społecznymi i gospodarczymi (Ministerstwo Rozwoju Regionalnego, 2008, s. 6; Rutkowski, 2009, s. 70). Na kanwie tych wskazań następuje próba dookreślenia good governance, która pozwala wskazać, jakie elementy w prowadzeniu polityk powinny być uwzględniane przez władze na każdym poziomie funkcjonowania administracji.

Idea good governance jest rzadko definiowana w literaturze, jednak należy uznać, że dobre rządzenie stało się normatywną koncepcją wartości, wskazującą na fakt, że akt rządzenia musi odbywać się przy zachowaniu interakcji pomiędzy podmiotami sprawującymi władzę a grupami społecznymi oraz organizacjami społecznymi. Koncepcja zakłada również, że inicjatywa obywatelska jest jednym z kluczowych elementów demokracji. Współpraca aktorów lokalnych opiera się na założeniu, że organizacje obywatelskie są wspierane w swoich działaniach przez władze samorządowe. Społeczność według koncepcji nie jest jedynie wyborcą, ale współdecyduje i współkreuje lokalne wartości i polityki. Często definiowanie pojęcia good governance zastępowane jest wskazywaniem zasad, na których opiera się cała koncepcja. Podejście do polityki rozwoju lokalnego powinno wiązać się z kompleksowym patrzeniem władz lokalnych na gminę, która może być wspomagana poprzez współuczestnictwo aktorów lokalnych w procesach podejmowania decyzji. Taka postawa pozwala na zwiększenie roli narzędzi wykorzystywanych do prowadzenia polityki rozwoju lokalnego poprzez podniesienie poziomu identyfikacji społeczności lokalnej z tymi dokumentami. Staje się to możliwe poprzez współuczestnictwo w ich przygotowaniu. Partycypację społeczności lokalnej w kreowaniu polityk lokalnych można powiązać bezpośrednio z koncepcją good governance, która odnosi się do państw demokratycznych i opiera się na zasadach: przejrzystości, rozliczalności, partycypacji, społecznej inkluzji oraz skuteczności i efektywności (szerzej: Ministerstwo Rozwoju Regionalnego, 2008; Wilkin i in., 2008; Wilkin, 2013; Miłaszewicz, 2014). Dobrze 
rządzona gmina powinna wykorzystywać w prowadzeniu swoich działań zasady good governance, we wszystkich sferach funkcjonowania samorządu lokalnego. Stanowisko takie pozwala wprowadzić zasady współuczestnictwa w procesach decyzyjnych w szczególności w przypadku narzędzi o charakterze strategicznym (długookresowym), ponieważ wizja rozwoju jednostki terytorialnej powinna być ustalana $\mathrm{w}$ porozumieniu $\mathrm{z}$ aktorami lokalnymi. Jest to również ważne $\mathrm{z}$ punktu widzenia cykliczności w odniesieniu do władz lokalnych, które to organy mogą po 4 latach zniknąć z życia publicznego, a społeczność lokalna będzie musiała realizować założenia zawarte w dokumentach służących do zarządzania jednostką terytorialną. W przypadku wybranych dokumentów krótkookresowych, należy również uwzględniać potrzebę uczestnictwa obywateli, czego przykładem staje się promowany w Polsce od kilku lat budżet obywatelski czy fundusz sołecki w gminach posiadających tego rodzaju jednostki pomocnicze.

Z punktu widzenia gminy należy uznać, że wszystkie zasady good governance powinny być stosowane $\mathrm{w}$ środowisku lokalnym. Przejrzystość polityki rozwoju lokalnego powinna wiązać się z czytelnością i dostępnością dokumentów strategicznych kreowanych przez władze lokalne. Każdy aktor lokalny powinien mieć dostęp do narzędzi polityki rozwoju lokalnego, dzięki czemu możliwe jest zapoznanie się z ich wytycznymi na każdym etapie ich funkcjonowania. Przejrzystość wiąże się również z koniecznością tworzenia dokumentów, które będą rozumiane przez społeczność lokalną, czyli pozbawionych sformułowań specjalistycznych. W przypadku ich stosowania należy uwzględnić potrzebę wyjaśnienia stwierdzeń, aby każdy aktor lokalny mógł w pełni zrozumieć przekaz dokumentu. Drugą stroną przejrzystości polityki rozwoju lokalnego jest proces informowania o możliwości partycypacji w procesie decyzyjnym podczas tworzenia dokumentów oraz upublicznianie wszelkich informacji związanych z ważnymi decyzjami, dotyczącymi wspólnoty gminnej.

Dzięki realizacji zasady przejrzystości możliwe jest urzeczywistnienie zasady rozliczalności. Dostęp do narzędzi wykorzystywanych w polityce rozwoju lokalnego oraz uczestnictwo w procesach ich tworzenia pozwalają na kontrolowanie działań podejmowanych przez władze lokalne. Rozliczalność ma szczególne znaczenie dla władz lokalnych, których decyzje weryfikowane są w cyklu wyborczym. Społeczność lokalna dzięki przejrzystości i dostępności strategicznych dokumentów gminy może w sposób świadomy ocenić osiągnięcia włodarzy na koniec ich kadencji. Podobnie można wykorzystać tę cechę w przypadku zakończenia okresu, na który narzędzie zostało opracowane. Możliwa jest bowiem ocena pozwalająca wskazać, które cele zostały osiągnięte w pełni, które częściowo, a których nie udało się zrealizować. Pomocne w tym przypadku mogą okazać się elementy wskazywane jako narzędzia ewaluacji działań strategicznych, które coraz częściej pojawiają się w instrumentach wykorzystywanych w kierowaniu jednostką samorządową. Mają one również zapewniać monitoring w całym okresie funkcjonowania dokumentu strategicznego. 
Najważniejszym elementem wynikającym z koncepcji good governance jest partycypacja społeczna. W odniesieniu do pewnych narzędzi polityki rozwoju lokalnego udział społeczny w procesach przygotowywania dokumentów zapewniony jest poprzez zapisy ustawowe. Dzieje się tak chociażby w przypadku studium uwarunkowań i kierunków zagospodarowania przestrzennego oraz miejscowych planów zagospodarowania przestrzennego, dla których odpowiednio w artykule 11 i 17 ustawy o planowaniu i zagospodarowaniu przestrzennym (Dz. U. 2003, $\mathrm{nr} 80$, poz. 717) przewidziano czynne uczestnictwo społeczności lokalnej w procesie uchwalania tych dokumentów. W podobny sposób partycypacja społeczna możliwa jest w odniesieniu do gminnych programów ochrony środowiska, co uregulowane jest w prawie ochrony środowiska (Dz. U. 2001, nr 62, poz. 627) oraz ustawie o udostępnianiu informacji o środowisku i jego ochronie, udziale społeczeństwa w ochronie środowiska oraz o ocenach oddziaływania na środowisko (Dz. U. 2008, nr 199, poz. 1227). Oba akty prawne wskazują na możliwość uczestnictwa społeczności lokalnej w ochronie środowiska, jednak podobnie jak w przypadku planowania przestrzennego sprowadza się to do możliwości składania wniosków i uwag.

Pozostałe dokumenty wykorzystywane jako narzędzia polityki rozwoju lokalnego co do zasady nie posiadają bezpośrednich wskazań w przepisach prawnych o potrzebie ich konsultowania ze społecznością lokalną. Większe możliwości w tym zakresie posiadają organizacje pożytku publicznego oraz organizacje pozarządowe, z którymi władze lokalne mają obowiązek konsultowania projektów aktów prawa miejscowego w dziedzinach dotyczących działalności statutowej samorządu. Uregulowania te wynikają z zapisów ustawy o działalności pożytku publicznego i o wolontariacie (Dz. U. 2003, nr 96, poz. 873).

Ważnym elementem good governance jest integrowanie społeczności lokalnej, co można utożsamiać $\mathrm{z}$ inkluzją społeczną opisywaną w literaturze przedmiotu. Polega to na włączaniu w procesy partycypacji wszystkich grup społecznych, aby nie dopuszczać do wykluczenia w jednostce lokalnej. Inkluzja społeczna powinna dotyczyć również ubogiej społeczności, która także tworzy wspólnotę lokalną (Reid, 2002, s. 102-103).

Ostatnim elementem wskazywanym w rozważaniach jest skuteczność i efektywność polityk prowadzonych na obszarze gminy. Powinna opierać się ona na ocenie dostępności narzędzi i weryfikacji, które z dokumentów obligatoryjnych i fakultatywnych wykorzystywane są w gminach. Skuteczność poszczególnych polityk wiąże się z realizacją ich założeń, które są oceniane $\mathrm{w}$ trakcie realizacji poszczególnych celów (ocena on-going) oraz na koniec funkcjonowania dokumentu (ocena ex post). Dokonanie tych ocen może być zestawione z oceną ex ante wykonywaną na potrzeby określenia konkretnych działań przed wdrożeniem dokumentu. Podobnie rzecz ma się w przypadku oceny przestrzeni oraz zmian zachodzących w zagospodarowaniu przestrzennym na terenie gminy. 
Efektywność działań władz lokalnych nierozerwalnie związana jest z potencjałem pracowniczym $i$ jego przygotowaniem do zarządzania jednostką terytorialną. Odpowiednie kwalifikacje kadry pozwalają zwiększyć efektywność działań, które wynikają z realizacji dokumentów wspierających politykę rozwoju lokalnego. Jakość świadczonych usług i ich ocena przez społeczność lokalną stanowią również miernik efektywności polityk prowadzonych przez władze lokalne w gminach (Hambleton, 2002, s. 147-160). Nie można zapominać o efektywności ekonomicznej, która zakłada ocenę relacji nakładów i otrzymanych efektów, które jednak trudno jest wycenić wartością pieniężną, szczególnie, że z założenia działania prowadzone w samorządach lokalnych mają wpływać na poziom życia mieszkańców i nie są nastawione na zysk.

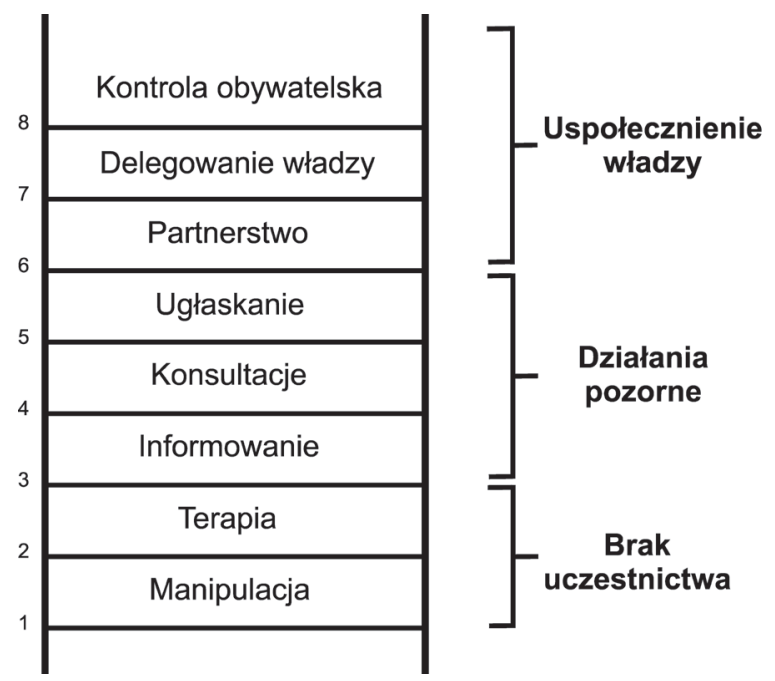

Rysunek 2. Drabina partycypacji

Źródło: Sherry Arnstein (1969, s. 217)

Koncepcja good governance opiera się na współdecydowaniu społeczności o polityce rozwoju lokalnego. Istotna jest nie tylko struktura podmiotów biorących udział w procesie współdecydowania, ale także to, na jakim poziomie tych działań znajduje się gmina. Dla oceny stopnia zaawansowania współrządzenia posłużyć może opracowana pod koniec lat 60. przez Sherry Arnstein (1969, s. 217) drabina partycypacji. Drabina partycypacji pozwala na określenie poziomu zaangażowania obywateli $\mathrm{w}$ decyzje podejmowane $\mathrm{w}$ odniesieniu do ich wspólnoty lokalnej. Pierwsze szczeble drabiny wskazują na brak uczestnictwa w podejmowaniu decyzji. Drugą grupą są działania pozorne, które pozwalają na zapoznanie się z działaniami podejmowanymi przez władze lokalne oraz party- 
cypację, jednak bez zapewnienia wdrożenia rozwiązań wypracowanych podczas konsultacji. Ostatnie trzy stopnie drabiny związane są natomiast z podejmowaniem działań i inicjatyw na równi z władzami lokalnymi bądź też przekazanie władzy w ręce obywateli, co stwarza możliwości lepszego dostosowania działań do potrzeb mieszkańców.

W literaturze przedmiotu często wskazuje się na fakt, że partycypacja społeczna w krajach postkomunistycznych nie jest na wysokim poziomie, przez co w wielu przypadkach można mówić jedynie o symbolicznym uczestnictwie lub wręcz o braku partycypacji (Reid, 2002, s. 95-98; Petrova, 2011, s. 758-762). $\mathrm{Z}$ jednej strony wynika to z podejścia społeczności lokalnych do własności publicznej, wobec której mogą podejmować decyzje i współpartycypować w działaniach na ich rzecz. Często postawa ta ma charakter bierny do momentu, gdy nie odnosi się do własności konkretnego mieszkańca. Po drugiej stronie rozważań leży nastawienie władz lokalnych do współrządzenia, podejście to wciąż ewoluuje, dzięki czemu w najbliższej przyszłości można spodziewać się większej liczby projektów, które z założenia będą promowały współdziałanie we wspólnotach samorządowych. Pozwoli to również na „wspinanie” się po stopniach drabiny partycypacji z możliwością osiągnięcia jej najwyższych szczebli (rys. 2). Uzależnić należy to od budowy relacji pomiędzy władzą a społecznością lokalną oraz tworzenia katalogu dobrych praktyk w tym zakresie.

\subsection{Partycypacja w polityce rozwoju lokalnego}

Model działań w samorządzie lokalnym powinien polegać na łączeniu podejścia menadżerskiego z podejściem zarządzania publicznego. Hybrydowe podejście pozwala na osiąganie lepszych efektów w zakresie zarządzania jednostką terytorialną, co osiąga się poprzez identyfikację obywateli z rozwiązaniami przyjętymi przez władzę lokalną. Wynika to z faktu, że społeczność lokalna włączona w procesy zarządzania jednostką terytorialną może tworzyć wartość dodaną w postaci wskazywanych rozwiązań i kierunków rozwoju gminy. W procesie współrządzenia wiele $\mathrm{z}$ elementów finalnych rozwiązań, powstaje po stronie mieszkańców, którym bliższe są problemy społeczności lokalnej. Zadaniem menadżera w procesie zarządzania jednostką terytorialną jest kanalizowanie pomysłów i wskazywanie możliwych sposobów wprowadzenia ich do dokumentów strategicznych oraz możliwości ich realizacji (rys. 3).

Hybrydowe podejście pozwala skuteczniej zarządzać jednostką terytorialną, co również wpisuje się w założenia koncepcji good governance. Skuteczność ta rośnie bowiem w obszarze szerokiego spojrzenia na gminę oraz lepszego rozumienia realizowanych celów. Dzięki temu efekty polityk cząstkowych mogą być szybciej dostrzeżone przez społeczności lokalne. 


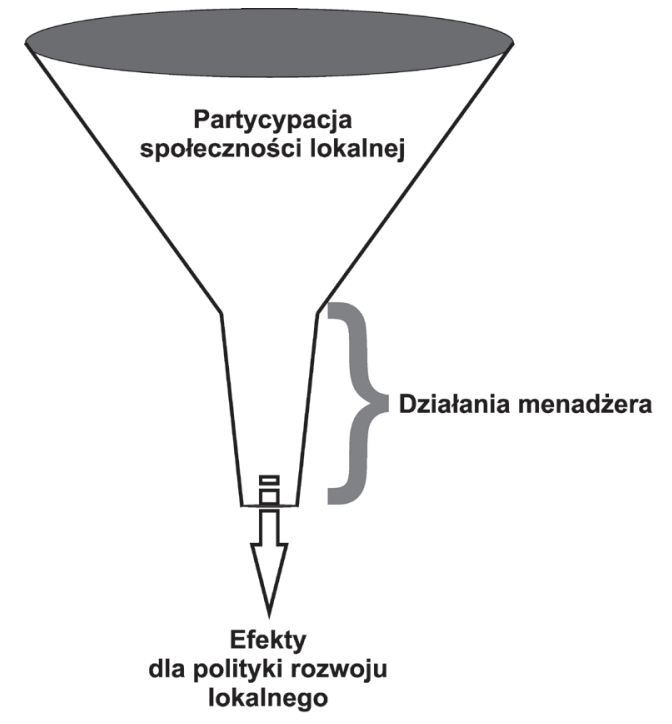

Rysunek 3. Efekt połączenia podejścia menadżerskiego i partycypacyjnego w polityce rozwoju lokalnego

Źródło: opracowanie własne

Wskazywane podejście pozwala na stwierdzenie faktu, że partycypacja społeczna w kreowaniu polityk rozwoju lokalnego zależy od władz, które powinny być inicjatorem działań w tym zakresie. Zależy ona również od społeczności lokalnej, która musi otworzyć się na propozycje władzy i wykazać się zaangażowaniem obywatelskim. O ile otwartość władz lokalnych na partycypację społeczną z roku na rok wzrasta, to mało jest badań, które pozwalają zidentyfikować podejmowane inicjatywy, jak również sposoby ich realizacji czy wykorzystywane w tym celu instrumentarium. Łatwiejszej ocenie podlegają natomiast działania podejmowane przez społeczność lokalną, dzięki którym mieszkańcy mogą wpływać na kształt swojej miejscowości i podejmowane przez władze lokalne decyzje.

Wyniki badań prowadzonych przez Centrum Badania Opinii Społecznej (CBOS) w 2012 r. pokazują, że od roku 1992 do 2010 zdaniem respondentów ich wpływ na sprawy związane z funkcjonowaniem podstawowej jednostki terytorialnej systematycznie rósł i w 2010 osiągnął $52 \%$ respondentów. W tym samym roku $45 \%$ respondentów uważało, że nie ma możliwości wpływania na sprawy rozwoju gminy. Ostatni rok (2012), dla którego wyniki badania były dostępne, pozwala wnioskować, że relacja ta wyniosła 50\% i $47 \%$, odpowiednio dla osób uznających, że mają wpływ na sprawy związane z funkcjonowaniem gminy i osób uważających, że takiego wpływu nie posiadają. Aktywność w działaniach lokalnych bądź krajowych przekłada się na poczucie wpływu na sprawy 
publiczne. Większość respondentów wskazujących przynajmniej jedną formę zaangażowania wyraża przekonanie posiadania wpływu na działania podejmowane w społecznościach lokalnych oraz w kraju (CBOS, 2012, s. 2).

Badanie wpływu na sprawy lokalne związane jest również z aktywnością społeczności lokalnej w wyborach samorządowych. Dane prezentowane na stronach internetowych Państwowej Komisji Wyborczej (PKW), zebrane w roku 2014, pokazują, że frekwencja wyborcza wyniosła ponad $47 \%$ i był to porównywalny wynik do wyborów samorządowych poprzedniej kadencji. Rok 2006 zgromadził w lokalach wyborczych blisko $40 \%$ głosujących, co było niższym wynikiem w odniesieniu do roku 2002, kiedy głosowało ponad $44 \%$ uprawnionych. Dane te pokazują, że sytuacja w sferze odpowiedzialności za działania samorządowe nie wykracza ponad pięćdziesięcioprocentowy próg, co zbieżne jest $\mathrm{z}$ badaniami przeprowadzonymi przez CBOS w $2012 \mathrm{r}$.

$\mathrm{Z}$ koncepcją good governance i polityką rozwoju lokalnego powiązany jest również budżet obywatelski, który w ostatnim czasie jest mocno dyskutowany i ewaluowany. Zgodnie $z$ badaniami prowadzonymi przez Instytut Obywatelski (Kębłowski, 2014, s. 4) działania związane z realizacją budżetu obywatelskiego podjęło ponad 80 miast w kraju. Oprócz tego na podobne posunięcie zdecydowały się władze kilku powiatów i województw. Analiza liczby ludności miast wykorzystujących budżet obywatelski wskazuje, że są to jednostki o różnej wielkości. Pionierem czystej formy budżetu obywatelskiego w Polsce był Sopot, który ideę tą wdrożył w 2011 r. (Gerwin, Grabowska, 2012, s. 100). Dzięki ewaluacji można ocenić zaangażowanie społeczne w to narzędzie. Okazuje się, że rozpiętość odsetka aktywnych uczestników w działaniach z zakresu budżetów obywatelskich waha się od około 2\% w Rybniku do blisko 40\% w Zielonej Górze. Pokazuje to, że zaangażowanie mieszkańców w proponowane przez władze lokalne przedsięwzięcia związane ze współrządzeniem nie zawsze spotyka się z pozytywnym odbiorem społeczności lokalnej. Ważnym źródłem wsparcia dla budżetów jest również Internet, za pomocą którego w Łodzi na budżet obywatelski 2015 zagłosowało 75,9\% wszystkich uczestników. Pokazuje to, że nowe technologie wykorzystywane są chętnie przez osoby partycypujące w działaniach samorządów.

Aktywność społeczności lokalnej powinna mieć szeroki zakres, wykraczający poza obszar związany z wyborami samorządowymi czy polityką budżetową gminy. Uczestnictwo społeczności lokalnych w kreowaniu polityki przestrzennej, środowiskowej czy tym bardziej opracowywaniu dokumentów strategicznych jest bardzo trudne, a ewentualne badania i analizy są często oparte na wskazaniach dla pojedynczych gmin. Analizy prowadzone przez autora pozwalają stwierdzić, że w planowaniu przestrzennym Łodzi po roku 2006 do 25 sporządzonych planów wniesiono 454 uwagi. Należy skonstatować, że średnia liczba uwag wnoszona do miejscowego planu zagospodarowania przestrzennego, bez uwzględniania obszaru, który obejmowało opracowanie, wynosi w trzecim co do wielkości mieście Polski jedynie 18. Mieszkańcy Łodzi podczas partycypacji w planowaniu 
przestrzennym zgłaszają najczęściej od 1 do 10 uwag. Drugim, co do liczebności, przedziałem jest ten, który odnosi się do planów zagospodarowania przestrzennego, do których nie zostały wniesione uwagi.

Należy podkreślić, że jeszcze trudniej uzyskać informacje na temat partycypacji społecznej w opracowywaniu dokumentów takich jak strategie rozwoju, co wynika z fakultatywności społecznego uczestnictwa w ich tworzeniu. Władze lokalne niejednokrotnie pomijają ten element z uwagi na możliwość przyspieszenia procesu uchwalenia dokumentów. Częsta jest również praktyka, że partycypacja dotyczy organizacji pożytku publicznego oraz organizacji pozarządowych z pominięciem pozostałych aktorów lokalnych.

Podejmowane działania w polityce rozwoju lokalnego powinny zmierzać do upublicznienia i udostępnienia jak najszerszemu gronu zarówno dokumentów już funkcjonujących w gminach, jak i tych, które są dopiero w trakcie opracowywania. Takie podejście władz lokalnych, promujące otwartość w stosunku do społeczności lokalnych, pozwala na lepsze zrozumienie procesów zachodzących w podstawowej jednostce podziału administracyjnego kraju, jak również pozwala na lepsze zapoznanie się z potrzebami ludności.

\section{Systemy informacji przestrzennej wsparciem dla good governance}

\subsection{Systemy informacji przestrzennej w podstawowej jednostce podziału terytorialnego}

Działania władz lokalnych powinny zmierzać do upowszechniania idei społeczeństwa informacyjnego we wszystkich obszarach funkcjonowania samorządu lokalnego. Wsparciem dla tego rodzaju przedsięwzięć mogą być systemy informacji przestrzennej (SIP). Najbardziej efektywnym dla działań podejmowanych w gminach okazuje się system informacji o terenie (Land Information System - LIS), który podobnie jak GIS (Geographical Information System) jest kategorią systemów informacji przestrzennej, z tą różnicą, że odpowiada mapom wielkoskalowym. Z definicji LIS mapami wielkoskalowymi są opracowania od 1: 500 do 1: 5000. W konsekwencji tak wskazanej skali, LIS okazuje się najlepszym narzędziem do wspomagania procesów decyzyjnych oraz wsparcia prowadzenia polityk lokalnych w zgodzie z ideą good governance.

Systemy informacji przestrzennej, a w szczególności systemy informacji o terenie określone zostały przez Międzynarodową Federację Geodetów (FIG) jako środek do podejmowania decyzji o charakterze prawnym, administracyjnym i gospodarczym oraz element pomocy w planowaniu i rozwoju. Zgodnie $\mathrm{z}$ założeniami FIG system ten składa się z bazy danych o terenie utworzonej dla 
określonego obszaru oraz metod i technik systematycznego pozyskiwania, aktualizowania i udostępniania danych, a jego podstawą jest jednolity sposób identyfikacji przestrzennej, wykorzystywany do tworzenia relacji pomiędzy danymi systemu i innych systemów przestrzennych (United Nations, 2005, s. 71-72). Dodatkowo systemy informacji o terenie są narzędziem, które pozwala na analizowanie oraz interpretację danych posiadających odniesienie przestrzenne. Podejmowane działania, pozwalają badać relacje pomiędzy różnego rodzaju danymi oraz ich wizualizowanie.

LIS pozwala na wykorzystywanie go w wielu obszarach, takich jak planowanie przestrzenne, ekonomia, rolnictwo czy urbanistyka. Przyczynia się również do zwiększenia efektywności w samorządach lokalnych poprzez ułatwienie procesu nakładania na siebie danych o różnym zasięgu tematycznym (Wolfe, Neale, 1988, s. 464). Podejście takie pozwala na zachowanie zgodne z ideą zrównoważonego rozwoju poprzez możliwość wskazywania wzajemnych relacji między poszczególnymi obszarami funkcjonowania miasta.

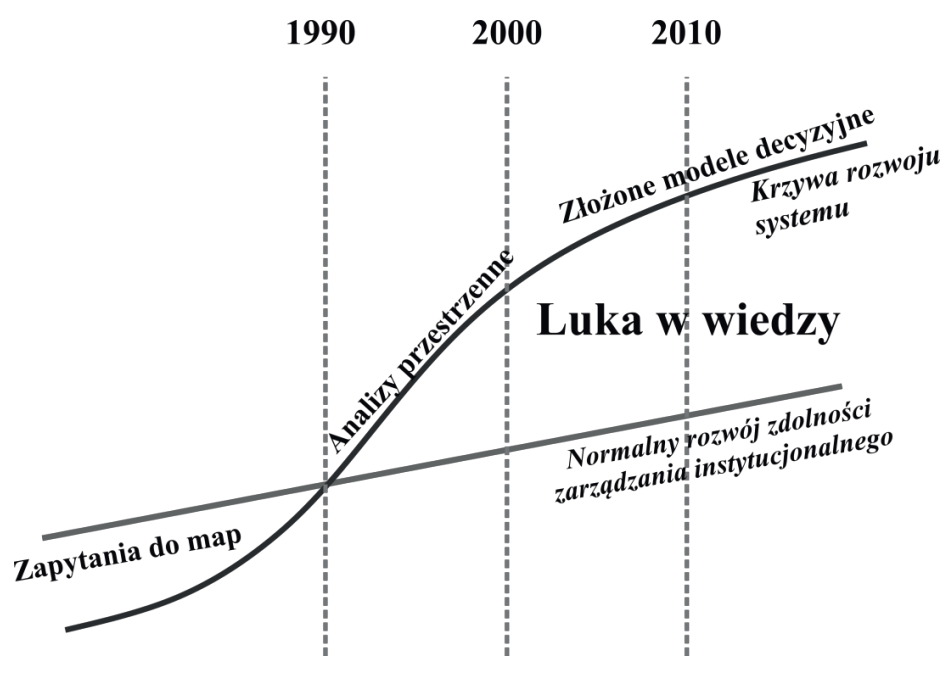

Rysunek 4. Mechanizm powstawania luki w wiedzy a rozwój GIS

Źródło: Tomlinson, 2007, s. 206

Ważnym elementem w rozwoju systemów informacji był powiązany z nim postęp w dziedzinie sprzętu komputerowego. Upowszechnienie komputerów osobistych (personal computer - PC) skutkowało tym, że od lat 90. XX w. obserwuje się coraz szybszy rozwój systemów informacji przestrzennej. Rozwój ten jest dużo szybszy niż rozwój i postęp technologiczny w administracji publicznej, 
przez co administracja publiczna nie nadąża za zmianami zachodzącymi w sferze LIS. Generuje to ryzyko pogłębiania się luki w wiedzy odnoszącej się do możliwości wykorzystania systemów LIS w działaniach związanych z polityką rozwoju lokalnego (rys. 4) (Tomlinson, 2007, s. 204-207). Jak pokazują badania dotyczące wykorzystania systemów informacji przestrzennej w administracji publicznej, pomimo wiedzy na temat możliwości tych narzędzi i ich przydatności w działaniach samorządowych, władze lokalne oraz podległe im jednostki nie decydują się na wykorzystywanie LIS w zarządzaniu gminą. Jest to szczególnie zauważalne w przypadku małych i średnich gmin miejskich oraz gmin miejsko-wiejskich i wiejskich (Feltynowski, 2012; 2013a; 2013b; 2013c).

Niezależnie od tego informacja przestrzenna towarzyszy władzom lokalnym. Zauważane jest to również przez Unię Europejską, która dała temu wyraz, wdrażając Dyrektywę INSPIRE (Dz. U. L 108 z 25.4.2007) wskazującą obszary wykorzystania informacji przestrzennej na różnych szczeblach, włączając $\mathrm{w}$ to poziom lokalny. Wynika to również z założeń, że około 80\% decyzji administracyjnych ma związek z informacją przestrzenną (Litwin, Myrda, 2005, s. 9).

Należy podkreślić, że LIS pozwala na integrację informacji ze sfery społecznej, kulturowej, ekonomicznej i środowiskowej z wykorzystaniem technologii komputerowych. LIS jest narzędziem pozbawionym możliwości ingerencji politycznej, a jednocześnie pozwala na budowanie relacji między społecznością lokalną i władzami gminy. Co ciekawe, oprócz tych własności LIS umożliwia patrzenie na jednostkę terytorialną kompleksowo, przez co łatwiej zrozumieć wpływ decyzji związanych z polityką rozwoju na inne sfery funkcjonowania danej jednostki terytorialnej oraz na gminę jako całość. Umożliwia to również określenie wpływu na otoczenie oraz oddziaływanie otoczenia na daną jednostkę terytorialną. Podejście takie może przyczynić się do łatwiejszego dostrzegania i zrozumienia zmian zachodzących w środowisku lokalnym. Wnioski płynące z wykorzystania informacji przestrzennej w systemach LIS niosą ze sobą pozytywne skutki zarówno dla działań podejmowanych przez władze lokalne, jak również dla rządzonej społeczności lokalnej. Wynika to z otwartości systemu, który może być wykorzystywany przez osoby prywatne oraz przez specjalistów.

\subsection{Wykorzystanie systemów informacji przestrzennej w polityce rozwoju lokalnego}

Użytkowanie systemów informacji przestrzennej do celów kreowania polityk sektorowych w zgodzie z zasadami partycypacji społecznej ma bogatą historię w krajach skandynawskich. Dobre praktyki w tym zakresie szczególnie zauważalne są w Finlandii. Procesy konsultowania oraz kreowania polityki przestrzennej oraz polityki środowiskowej opierają się na rozwiązaniach softGIS, które polegają na 
pozyskiwaniu danych przestrzennych z geoankiet. Założeniem twórców softGIS było połączenie ze sobą danych jakościowych (,miękkich” - soft) z danymi „twardymi" odnoszącymi się konkretnej lokalizacji w przestrzeni (Kahila, Kyttä, 2009, s. 26-29; Hasanzadeh, 2014, s. 38). Tak skonstruowane narzędzie pozwala gromadzić dane, które tworzą bogate bazy danych, wykorzystywane przez władze do podejmowania strategicznych decyzji (Rantanen, Kahila, 2009, s. 1981-1982; Kahila, Kyttä, 2010, s. 15-17; Czepkiewicz, 2013, s. 18-19). Metoda softGIS jest elementem opisywanego w literaturze przedmiotu PPGIS (Public Participation Geographic Information System), który promuje podejście bottom up w działaniach władz lokalnych oraz opieranie się na wiedzy społeczności lokalnej przekazywanej za pośrednictwem Internetu i technologii informacyjno-komunikacyjnych. Założeniem metody softGIS jest otwartość oraz możliwość jej wykorzystania tak przez młodzież szkolną, jak również osoby starsze, co umożliwia dotarcie do szerokiego grona osób, które mogą wesprzeć informacją władze lokalne (Kahila, 2008, s. 7-8).

W Polsce trudno jest obecnie znaleźć przykłady wykorzystania metody softGIS w procesach związanych z kreowaniem polityki przestrzennej gminy czy polityki środowiskowej. Należy jednak uznać, że musi dojść do implementacji tego rodzaju narzędzia wspierającego proces podejmowania trafnych decyzji. Dobrą praktyką w tym zakresie jest prowadzony przez Fundację Sendzimira projekt „Licz na zieleń", który zakładał partycypacyjny model zarządzania zielenią w mieście. Projekt docelowo realizowany był w trzech miastach: Krakowie, Łodzi i Poznaniu. Przesłanką projektu było zrównoważone podejście do zieleni w mieście w oparciu o dialog pomiędzy mieszkańcami, organizacjami pozarządowymi oraz przedstawicielami administracji lokalnej, co miało przyczynić się do zmniejszenia liczby konfliktów w przestrzeni związanych z zarządzaniem zielenią. Do celu realizacji projektu stworzony został geoportal z wykorzystaniem metody softGIS, dzięki czemu aktorzy lokalni mogli wskazać miejsca, w których spędzają czas w otoczeniu zieleni, czy też wartościowe, w ich odczuciu, miejsca w otoczeniu zieleni. Autorzy badania prosili również o wskazanie miejsc, które respondenci wzbogaciliby o zieleń, bądź tych, gdzie zieleń jest zaniedbana lub potrzebuje reorganizacji. Działania te dzięki promocji i działaniom Fundacji w okresie pół roku zgromadziły ponad 12 tys. zaznaczeń na mapach trzech miast. W przypadku Łodzi było to blisko 4400 wskazań związanych z zielonymi przestrzeniami Łodzi (rys. 5).

Działania władz lokalnych mogą opierać się na badaniach prowadzonych w podobny sposób, jak miało to miejsce w przypadku projektu „Licz na zieleń”. Jest to podkreślane $\mathrm{w}$ raporcie $\mathrm{z}$ projektu, ponieważ deklarację wykorzystania pozyskanych danych zgłosiły Wydział Kształtowania Środowiska w Krakowie oraz Miejska Pracownia Urbanistyczna w Lodzi (Fundacja Sendzimira, 2014, s. 2). Pokazuje to, że dane pozyskiwane od mieszkańców i użytkowników przestrzeni miejskiej są pożądane przez jednostki podległe władzom miasta, brakuje natomiast własnych inicjatyw w tym zakresie. Pozwoliłoby to na budowanie 
zasobu danych, które mogłyby być wykorzystywane w planowaniu przestrzennym czy w procesach kształtowania zieleni miejskiej. Według analiz wynikających $\mathrm{z}$ raportu największym zaangażowaniem w partycypację wykazały się osoby zamieszkujące Łódź, co zostało zmierzone poprzez liczbę zaznaczeń wprowadzaną przez jednego użytkownika (Fundacja Sendzimira, 2014, s. 4). Rozważania związane z opinią mieszkańców na temat zieleni w Łodzi pozwalają na wskazanie miejsc, osiedli czy dzielnic, które z punktu widzenia mieszkańców stanowią miejsca chętnie odwiedzane przez respondentów, czy lokalizacje wymagające interwencji władz miasta w zakresie inwestycji zielonych (Feltynowski, 2014).

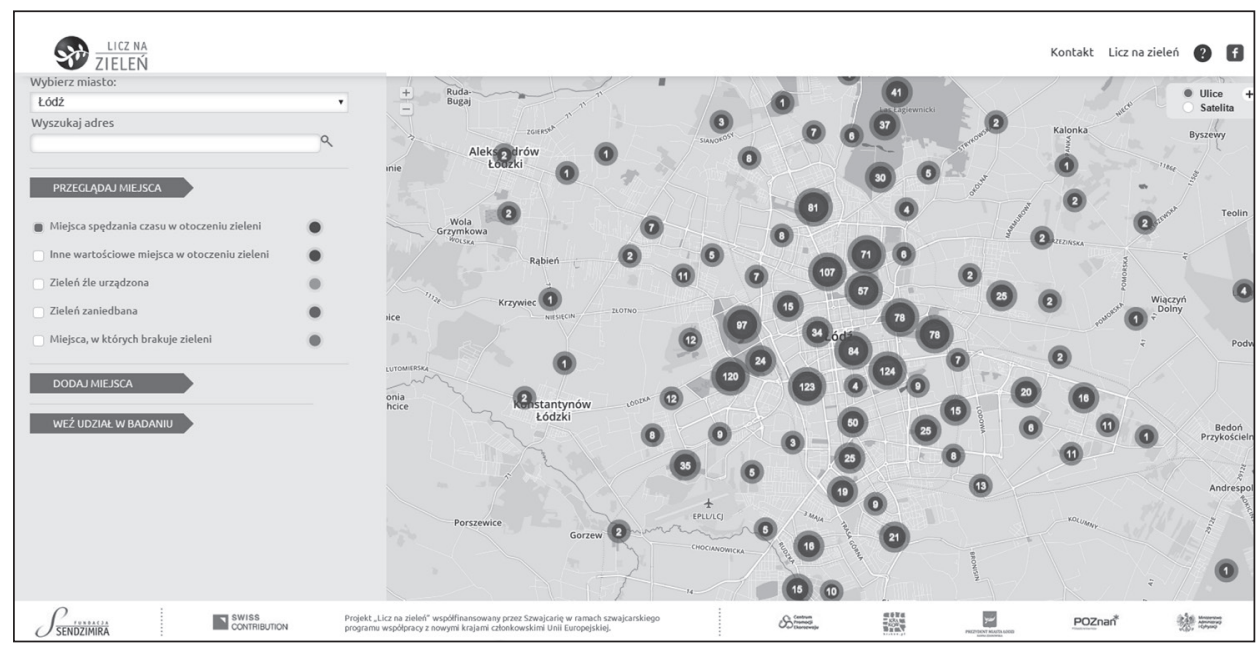

Rysunek 5. Projekt „Licz na zieleń” miejsca spędzania czasu wolnego w otoczeniu zieleni - Łódź

Źródło: http://lodz.licznazielen.pl/mapa-1 [dostęp 20 listopad 2014]

Wykorzystanie metody softGIS przez Fundację Sendzimira jest przykładem dobrej praktyki w zakresie partycypacyjnego zarządzania przestrzeniami zielonymi w mieście. Jednocześnie projekt wskazuje, w jaki sposób władze lokalne mogą pozyskiwać materiały od własnych mieszkańców oraz osób z zewnątrz w celu lepszego zarządzania jednostką terytorialną. Pozwala to również w łatwiejszy sposób zrozumieć potrzeby mieszkańców. Podobne konsultacje mogą być prowadzone również w odniesieniu do strategii rozwoju gminy czy lokalnych programów rewitalizacji, ponieważ dane „twarde” pozwalają odnieść wskazówki i odpowiedzi pochodzące z geoankiet do konkretnych miejsc. Wykorzystanie informacji w procesie tworzenia dokumentów strategicznych pozwala, w późniejszym czasie, na kontrolę efektów, co również zgodne jest z założeniami koncepcji good governance. 


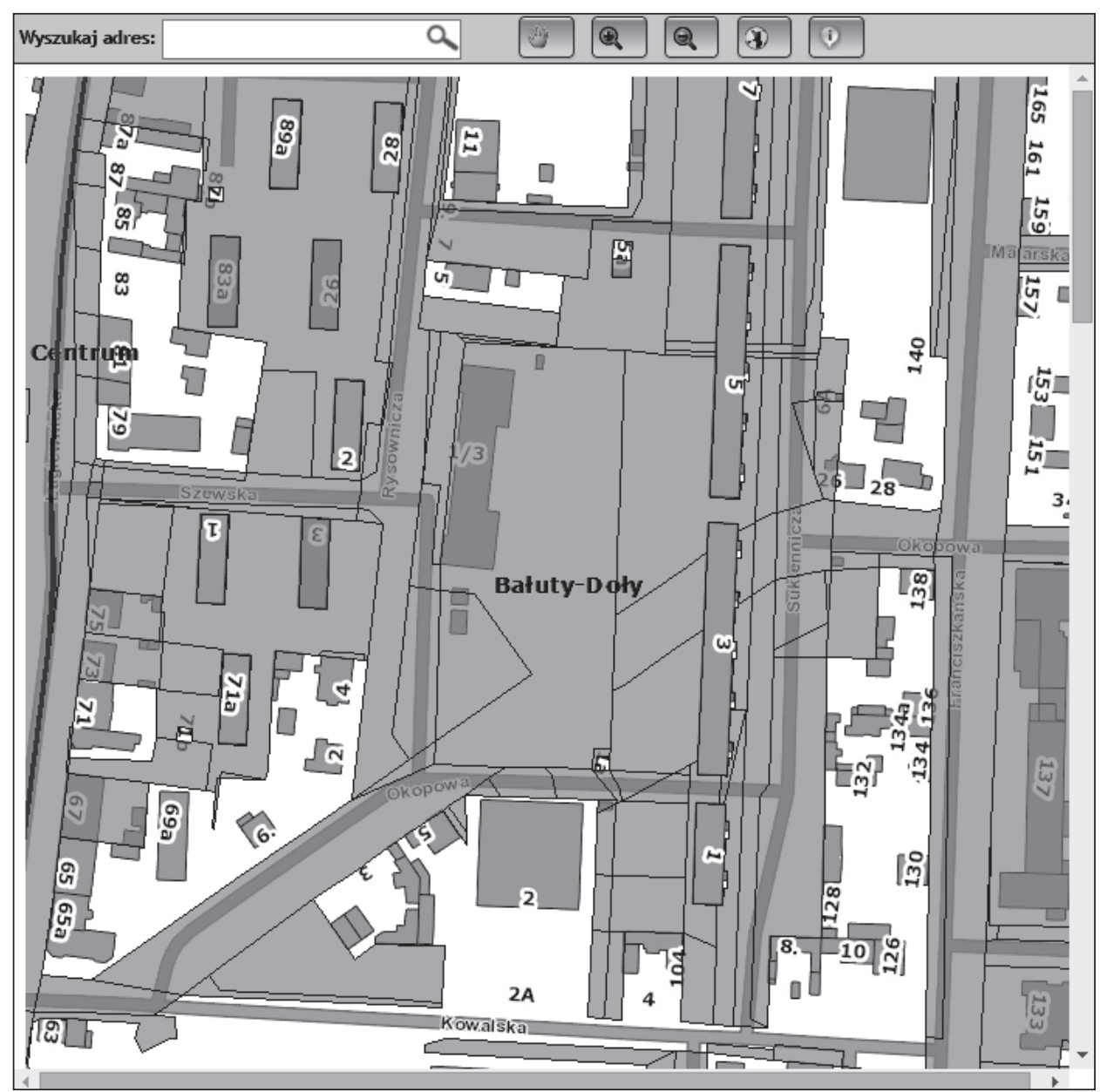

Rysunek 6. Fragment mapy własności gruntów - Łódź-Bałuty (kolor ciemnoszary - grunty należące do miasta lub pozostające w jego władaniu)

Źródło: http://budzet.dlalodzi.info/mapa-wlasnosci-terenu [dostęp 20 listopad 2014]

Działania z wykorzystaniem nowych technologii mają szczególne znaczenie dla dokumentów strategicznych, jednak mogą one wspierać poczynania związane chociażby z budżetami obywatelskimi. Aktywność taka wynika z założenia, że budżet obywatelski może być realizowany jedynie na obszarach, które są własnością miasta lub pozostają w jego władaniu. Dobrym przykładem może być Łódź, w której obostrzenie to w pierwszym roku funkcjonowania budżetu obywatelskiego nastręczało wielu problemów.

Mapa wykorzystywana $\mathrm{w}$ drugim roku funkcjonowania budżetu obywatelskiego (rys. 6) pozwala na weryfikację stanu własności działki. Posiadając tego 
typu dane, w połączeniu z możliwościami technologii softGIS prowadzić może do stworzenia kompleksowego systemu zgłaszania projektów w ramach budżetu obywatelskiego, który umożliwia automatyczną weryfikację własności terenu oraz wprowadzenie niezbędnych informacji na temat proponowanego projektu. Działania tego typu pozwalają wykorzystać informacje przestrzenne na kolejnych etapach budżetu obywatelskiego, tj. podczas wyboru projektów do głosowania i samego głosowania. Technologia softGIS stanowić mogłaby ważne narzędzie w procedurach odnoszących się do działań podejmowanych w obszarze budżetu obywatelskiego, co spójne jest z wykorzystaniem elektronicznego sposobu głosowania w Łodzi, który przyciągnął blisko $76 \%$ wszystkich partycypantów.

Konsekwencją prezentowanych praktyk może być wskazanie możliwości wykorzystania technologii SIP w kreowaniu polityk lokalnych. Wykorzystanie technologii SIP w procesach zarządzania gminą niesie ze sobą korzyści dla wszystkich aktorów lokalnych. Z punktu widzenia urzędów miast i gmin jako podstawową zaletę należy wskazać, że rozwijająca się technologia wraz z przepisami, które to regulują, narzuca konieczność przyjmowania odpowiednich standardów przy gromadzeniu, obróbce i zapisie danych przestrzennych. Jednolitość ta pozwala na tworzenie spójnych systemów informacji przestrzennej, które stają się podstawą realizacji poszczególnych polityk sektorowych.

Zebrane dane pozwalają wspierać działania władz lokalnych w polityce przestrzennej poprzez możliwość prowadzenia rejestru dokumentów oraz upowszechnianie ich w Internecie, dzięki czemu społeczność lokalna może zapoznać się z obowiązującym prawem lokalnym. Ważnym elementem wykorzystania systemów informacji przestrzennej w polityce przestrzennej jest możliwość prowadzenia konsultacji przy użyciu interaktywnych portali, co umożliwia wyrażanie opinii oraz wnoszenie uwag mieszkańców na temat wyłożonych projektów planów zagospodarowania przestrzennego czy też studium uwarunkowań i kierunków zagospodarowania przestrzennego. Dzięki wykorzystaniu tego rodzaju narzędzi interakcja społeczności lokalnej zyskuje na skuteczności oraz pozwala na podniesienie wskaźników partycypacji oraz świadomości mieszkańców o działaniach władz w zakresie polityki przestrzennej.

W zakresie polityki środowiskowej prowadzonej na szczeblu lokalnym systemy informacji przestrzennej stają się elementem wspierającym wydawanie decyzji na wycinkę drzew czy podłączania budynków do sieci wodno-kanalizacyjnej. Jak wskazano w projekcie „Licz na zieleń”, SIP może być wsparciem dla procesów konsultowania zagospodarowania terenów zielonych w gminach. W podobny sposób, wykorzystując systemy informacji przestrzennej, można konsultować wpływ planowanych przedsięwzięć na środowisko, co pozwoli na spełnienie wymogów ustawowych stawianych przed władzami lokalnymi. Podobnie jak w przypadku polityki przestrzennej zwiększy to efektywność działań władz lokalnych w zakresie zachęcania społeczności do uczestnictwa w konsultacjach społecznych oraz podniesie skuteczność głosu mieszkańców. 
Pozytywnych skutków wykorzystania SIP należy dopatrywać się również w odniesieniu do polityki gospodarczej prowadzonej na terenie gminy. Przy pomocy geoportali gminnych władze są w stanie informować o terenach inwestycyjnych oraz ich wyposażeniu (Feltynowski, 2009b, s. 54-57). Konsekwencją tego jest możliwość oceny, które z gminnych terenów inwestycyjnych cieszą się największym zainteresowaniem wśród potencjalnych inwestorów oraz jakie kroki należy poczynić, aby podnieść walory inwestycyjne w innej części gminy.

Ważnej roli SIP należy upatrywać również w polityce informacyjnej oraz promocyjnej. Wykorzystywanie wizualizacji z danymi przestrzennymi pozwala na promowanie jednostki terytorialnej w Internecie. Tego rodzaju działania mogą być nastawione na promocję różnych obszarów, wśród których wymienić można walory kulturowe czy środowiskowe.

Tak zdefiniowane systemy informacji przestrzennej w gminach wpływają na skuteczność i efektywność działań podejmowanych przez władze lokalne, co jest zgodne z zasadami good governance. Podobnie w wymiarze partycypacji społecznej należy uznać, że systemy informacji przestrzennej pozwalają na wsparcie tego procesu oraz otwarcie się na nowe grupy użytkowników przestrzeni gminy. Wiąże się to również z inkluzją społeczną rozumianą jako konieczność otwierania się władz lokalnych na głosy płynące od różnych grup społecznych zamieszkujących jednostkę terytorialną.

Wykorzystanie geoportali oraz metody softGIS pozwala wprowadzić kontrolę społeczną działań związanych z politykami sektorowymi. Dzięki wykorzystaniu baz danych przestrzennych możliwa jest również koordynacja różnych przedsięwzięć podejmowanych przez władze lokalne. Wykorzystanie tych narzędzi jako instrumentu konsultowania projektów polityk lokalnych staje się również elementem wpływającym na przejrzystość tych procesów. Wynika to z jednej strony z faktu, że narzędzia te wymagają upublicznienia, z drugiej strony - każdy $\mathrm{z}$ aktorów lokalnych jest w stanie uzyskać podstawowe informacje o już wskazanych uwagach, dzięki czemu można w prosty sposób ocenić, czy zostały one uwzględnione w finalnym kształcie polityki lokalnej. Należy pamiętać, że nowe technologie pozwalają na prowadzenie dialogu społecznego z władzami lokalnymi bez wprowadzania ograniczeń czasowych. Znaczy to, że systemy zbierania danych od mieszkańców mogą być aktywne przez cały czas, dzięki czemu nie będą one kojarzone jedynie z pojedynczymi akcjami konsultacyjnymi podejmowanymi przez władze.

\section{Podsumowanie}

Rozwój nowych technologii oraz wprowadzanie rozwiązań opartych na technologiach informacyjno-komunikacyjnych w samorządach lokalnych pozwala na przyspieszenie obiegu dokumentów oraz podniesienie efektywności działań 
władz lokalnych. Podejście takie zgodne jest również z założeniami przyjmowanymi na szczeblu Unii Europejskiej już od połowy lat 90. XX w. Kolejne etapy związane z implementacją technologii informacyjno-komunikacyjnych opierają się obecnie na rozwijaniu systemów informacji przestrzennej w oparciu o Dyrektywę INSPIRE.

Powinno to uświadomić władzom lokalnym, że nowe technologie mają wspierać proces kreowania polityki rozwoju lokalnego, a tym samym polityk cząstkowych. Podobnie coraz większa chęć angażowania się społeczności lokalnej w podejmowanie decyzji, związanych z lokalnym środowiskiem i politykami gminnymi, powinna skłaniać władze do szukania rozwiązań, które pozwolą w sposób kompleksowy budować politykę rozwoju lokalnego.

Dzięki narzędziom osadzonym w Internecie i wykorzystaniu ich w procesie partycypacji społecznej możliwe staje się poszerzenie grona odbiorców oraz ułatwienie prowadzenia konsultacji. Jak wskazują polskie praktyki w zakresie wykorzystania softGIS w partycypacyjnym zarządzaniu zielenią miejską, narzędzia tego typu nie były barierą zarówno dla młodzieży szkolnej, jak również dla seniorów (Fundacja Sendzimira, 2014, s. 2), którzy chętnie uczestniczyli w warsztatach związanych z nową formą partycypacji.

Ważnym zasobem dla władz lokalnych stają się informacje pozyskiwane drogą elektroniczną od różnych grup społecznych użytkujących miasta, a zasób ten jest nie do przecenienia w podejmowaniu trafnych decyzji. Dlatego istotnym staje się, aby władze lokalne dostrzegały potrzebę krzewienia idei współdecydowania oraz wykorzystywania do tego celu nie tylko standardowych narzędzi stosowanych od czasów przywrócenia samorządności lokalnej w Polsce. Kierunkiem płynącym z dobrych praktyk będzie bowiem wykorzystanie narzędzi softGIS, co w konsekwencji pozwoli na wdrażanie pozostałych zasad good governance i prowadzenie otwartej polityki opartej na wzajemnym zaufaniu wszystkich aktorów lokalnych.

\section{Bibliografia}

Antoszewski A., Herbut R. (red.) (2003), Leksykon politologii, Atla2, Wrocław.

Arnstein S. (1969), A leddar of citizen participation, „Journal AIP”, Vol. 35, No. 4, s. 216-224.

Blakely E. J. (1989), Planning local economic development. Theory and practice, ,Sage Library and Social Research", No. 168, Sage Publication, California, s. 57-72.

CBOS (2012), Komunikat z badań. Poczucie wptywu na sprawy publiczne i zaangażowanie obywatelskie, CBOS, Warszawa.

Chądzyński J., Nowakowska A., Przygodzki Z. (2007), Region i jego rozwój w warunkach globalizacji, Wydawnictwo Fachowe CeDeWu, Warszawa.

Czepkiewicz M. (2013), Systemy informacji geograficznej w partycypacyjnym zarzadzaniu przyrodą w mieście, „Zrównoważony rozwój - zastosowania”, nr 4/2013, s. 111-123. 
Dyrektywa 2007/2/WE Parlamentu Europejskiego i Rady z dnia 14 marca 2007 r. ustanawiająca infrastrukturę informacji przestrzennej we Wspólnocie Europejskiej (INSPIRE), Dz. U. L 108 z 25.4.2007.

Feltynowski M. (2009a). Polityka przestrzenna obszarów wiejskich. W kierunku wielofunkcyjnego rozwoju, Wydawnictwo Fachowe CeDeWu, Warszawa.

Feltynowski M. (2009b), Regionalny System Informacji Przestrzennej Województwa Łódzkiego jako czynnik rozwoju lokalnego gmin, [w:] F. Moterski (red.), Człowiek w obliczu nauki, techniki i sztuki: wspótczesne problemy nauk ekonomicznych, OKMN Łódź, Łódź, s. 52-59.

Feltynowski M. (2012), System informacji przestrzennej jako narzędzie podejmowania decyzji w gminach - badania wśród pracowników urzędów miast Łódzkiego Obszaru Metropolitalnego, Acta Scientiarum Polonorum. Geodesia et Descriptio Terrarum 11 (1) 2012, s. 29-38.

Feltynowski M. (2013a), The level of implementation of the informational function of spatial planning documents using GIS. The Polish example, Prace Naukowe Uniwersytetu Ekonomicznego we Wrocławiu (Research Papers of Wrocław University of Economics) 283/2013, s. 139-147.

Feltynowski M. (2013b), The use of geoinformation in rural and urban-rural gminas of Zgierz poviat - a pilot survey, „Bulletin of Geography. Socio-economic Series”, No. 22, s. 47-53.

Feltynowski M. (2013c), The use of geographical information systems in the urban communes of Łódź Metropolitan Area, „Management Research and Practice”, Vol. 5, Issue 1, s. 5-13.

Feltynowski M. (2014), Spatial information systems - a tool supporting planning process of green areas in accordance with the good governance concept, maszynopis.

Fundacja Sendzimira (2014), Świeże spojrzenie na zieleń. Geoankiety - nowe źródto informacji o mieście. Raport z projektu „Licz na zielen’”, http://uslugiekosystemow.pl/sites/default/files/ raport_final_press-1.pdf [dostęp 20.11.2014].

Gajl N. (1988), Instrumenty finansowe w zarządzaniu gospodarka narodowa, wyd. 2, PWE, Warszawa.

Gerwin M., Grabowska M. (2012), Budżet obywatelski, [w:] Partycypacja. Przewodnik Krytyki Politycznej, Wydawnictwo Krytyki Politycznej, Warszawa, s. 100-111.

Gorzelak G. (2000), Zewnętrzna interwencja jako czynnik rozwoju lokalnego (na przykładzie Programu Inicjatyw Lokalnych), „Studia Regionalne i Lokalne”, nr 3(3), s. 99-120.

Hambleton R. (2002), The New City Management, [w:] R. Hambleton, H. V. Savitch, M. Stewart (red.), Globalism and local democracy challenge and change in Europe and North America, Palgrave Macmillan, Basingstoke, s. 147-168.

Hasanzadeh K. (2014), Spatio-Qualitative Data Visualization: SoftGIS and Weighted Average Visualization, „Journal of Geosciences and Geomatics”, Vol. 2, No. 1, s. 38-41.

Hausner J. (red.) (1999), Komunikacja i partycypacja społeczna. Poradnik, Małopolska Szkoła Administracji Publicznej, Kraków.

http://opus.tkk.fi/dokumentit/softgis_03022006_bratislava_use.pdf [dostęp 18.11.2014].

http://www.uslugiekosystemow.pl/sites/default/files/raport_final_press-1.pdf [dostęp 18.11.2014].

Jastrzębska M. (2003), Polityka a strategia i zarzadzanie $w$ jednostce samorządu terytorialnego w sferze ogólnej i finansowej, „Samorząd Terytorialny”, nr 12, s. 3-18.

Kahila M. (2008), Possibilities of Webbased softGIS Method in Revealing Residents Evaluation Knowledge of the Living Environment, http://opus.tkk.fi/ dokumentit/softgis_03022006_bratislava_use.pdf [dostęp 20.11.2014].

Kahila M., Kyttä M. (2009), SoftGIS as a bridge-builder in collaborative urban planning, [w:] S. Geertman, J. Stillwell (red.), Planning support systems best practice and new methods, Springer Netherlands, s. 389-411.

Kahila M., Kyttä M. (2010), SoftGIS as a bridge builder in collaborative urban planning, [w:] S. Wallin at al. (ed.), Digital tools in participatory planning, Espoo Centre for Urban and Regional Studies Publications, s. 13-36. 
Kębłowski W. (2014), Budżet partycypacyjny. Ewaluacja, Instytut Obywatelski, Warszawa.

Kot J. (2003), Zarzadzanie rozwojem gmin a praktyka planowania strategicznego, Wydawnictwo Uniwersytetu Łódzkiego, Łódź.

Litwin L., Myrda G. (2005), Systemy Informacji Geograficznej. Zarządzanie danymi przestrzennymi w GIS, SIP, SIT, LIS, Helion, Warszawa.

Markowski T. (1999), Zarzadzanie rozwojem miast, PWN, Warszawa.

Miłaszewicz D. (2014), Problemy społecznej efektywności sektora publicznego, Studia Ekonomiczne. Zeszyty Naukowe Wydziałowe Uniwersytetu Ekonomicznego w Katowicach, nr 180, s. $163-173$.

Ministerstwo Rozwoju Regionalnego (2008), Koncepcja good governance - refleksje do dyskusji, Warszawa, https://www.mir.gov.pl/aktualnosci/fundusze_europejskie/Documents/koncepcja_ good_governance.pdf [dostęp 18.10.2014].

Needham B. (1982), Choosing the right policy instruments, Alderhorst, Hampshire.

Nowakowska A. (2000), Polityka rozwoju gminy w okresie transformacji systemowej, [w:] A. Jewtuchowicz (red.), Strategiczne problemy rozwoju miast i regionów, Zakład Ekonomiki Regionalnej i Ochrony Środowiska UŁ, Łódź, s. 11-36.

Noworól A. (2007), Planowanie rozwoju terytorialnego w skali regionalnej i lokalnej, Wydawnictwo Uniwersytetu Jagiellońskiego, Kraków.

Opałek K. (1986), Zagadnienia teorii prawa i teorii polityki, PWN, Warszawa.

Parysek J. J. (2001), Podstawy gospodarki lokalnej, Wydawnictwo Naukowe Uniwersytetu Adama Mickiewicza, Poznań.

Petrova T. (2011), Citizen participation in local governance in Eastern Europe: rediscovering a strength of civil society in the post-socialist world?, „Europe-Asia Studies”, Vol. 63, No. 5, s. $757-787$.

Podedworna H. (2013), Aktywizacja, partycypacja, wspótpraca: blaski i cienie, Acta Universitatis Lodziensis Folia Sociologica 44, Łódź, s. 11-24.

Pokładecki J. (2013), Rola aktywności gospodarczej samorzadu terytorialnego w rozwoju lokalnym, „Homines Hominibus”, Vol. 9, s. 51-62.

Potoczek A. (2003), Polityka regionalna i gospodarka przestrzenna, TNOiK, Toruń.

Rantanen H., Kahila M. (2009), The SoftGIS approach to local knowledge, „Journal of Environmental Management", No. 90, s. 1981-1990.

Regulski J., Kocon W., Ptaszyńska-Wołoczkowicz M. (1988), Władze lokalne a rozwój gospodar$c z y$, PWE, Warszawa.

Regulski J., Ptaszyńska M., Kaźmierska E. (1986), Instrumenty polityki przestrzennej. Założenia metodyczne i kierunki badań, [w:] Instrumenty polityki przestrzennej, Biuletyn KPZK PAN, zeszyt 130, KPZK PAN, Warszawa, s. 8-34.

Regulski J., Ptaszyńska M., Kaźmierska E. (1986), Instrumenty polityki przestrzennej. Założenia metodyczne i kierunki badań, [w:] Instrumenty polityki przestrzennej, Biuletyn KPZK PAN, zeszyt 130, KPZK PAN, Warszawa, s. 8-34.

Reid M. F. (2002), Rapid Transformations in Post-Socialist Cities: towards an Uncertain Future, [w:] R. Hambleton, H. V. Savitch, M. Stewart (eds.), Globalism and local democracy challenge and change in Europe and North America, Palgrave Macmillan, Basingstoke, s. 95-107.

Rogers V. (2006), Reforming regional and local development policy in France, „Land Use Policy” 23, s. 302-310.

Rutkowski M. (2009), Bank Światowy a poprawianie jakości rzązenia w zmieniającym się świecie. Sytuacja Polski i wyzwania kryzysu gospodarczego, „Zarządzanie Publiczne”, nr 3(9)/2009, s. 69-79.

Sartorius W., Pietras K., Mierzejewski M. (2009), Partycypacja społeczna w praktyce, Konsultatywa, Warszawa. 
Skica T. (2008), Instrumenty wspierania przedsiębiorczości przez samorząd terytorialny (na przykładzie gmin woj. podkarpackiego), „Samorząd Terytorialny”, 1-2, s. 43-62.

Sokół W., Żmigrodzki M. (red.) (1999), Encyklopedia politologii. Tom 1. Teoria polityki, Kantor Wydawniczy Zakamycze, Kraków.

Swianiewicz P. (2005), Nowe interpretacje teoretyczne polityki miejskiej, „Studia Regionalne i Lokalne", nr 4(22), s. 5-25.

Tomlinson R. (2007), Rozważania o GIS. Planowanie Systemów Informacji Geograficznej dla menedżerów, ESRI Polska, Warszawa.

United Nations (2005), Land administration in the UNECE region. Development trends and main principles, Geneva, http://www.unece.org/fileadmin/DAM/env/documents/2005/wpla/ECEHBP-140-e.pdf [dostęp 30.10.2014].

Ustawa z dnia 24 kwietnia 2003 r. o działalności pożytku publicznego i o wolontariacie, Dz. U. 2003, nr 96, poz. 873 z późn. zm.

Ustawa z dnia 27 kwietnia 2001 r. Prawo ochrony środowiska, Dz. U. 2001, nr 62, poz. 627 z późn. zm.

Ustawa z dnia 27 marca 2003 r. o planowaniu i zagospodarowaniu przestrzennym, Dz. U. 2003, nr 80, poz. 717 z późn. zm.

Ustawa z dnia 3 października 2008 r. o udostępnianiu informacji o środowisku i jego ochronie, udziale społeczeństwa w ochronie środowiska oraz o ocenach oddziaływania na środowisko, Dz. U. 2008, nr 199, poz. 1227 z późn. zm.

Ustawa z dnia 8 marca 1990 r. o samorządzie gminnym, Dz. U. 1990, nr 16, poz. 95 z późn. zm.

Wilkin J. (red.) (2013), Jakość rzadzenia w Polsce. Jak ja badać, monitorować i poprawiać?, Wydawnictwo Naukowe SCHOLAR, Warszawa.

Wilkin J., Fabrowska P., Hardt Ł., Kaczor T., Mackiewicz M., Michorowska M., Węcławska D. (2008), Badanie dotyczace stworzenia systemu wskaźników dla oceny realizacji zasady good governance $w$ Polsce, ECORYS Polska, Warszawa.

Wojciechowski E. (2003), Zarzadzanie w samorzadzie terytorialnym, Difin, Warszawa.

Wojtasiewicz L. (1997), Czynniki rozwoju lokalnego - nowe ujęcie metodologiczne, [w:] W. Maik (red.), Problematyka rozwoju lokalnego $w$ warunkach transformacji systemowej, Biuletyn KPZK PAN, zeszyt 177, KPZK PAN, Warszawa, s. 7-18.

Wolfe M. L., Neale C. M. U. (1988), Input development for a distributed parameter hydrologic model (FESHM), [w:] Modeling Agricultural, Forest and Rangeland Hydrology, Proceedings of American Society of Agricultural Engineers, St. Joseph, Michigan, s. 462-469.

World Bank (1989), Sub-Saharan Africa, from crisis to sustainable growth: A long-term perspective study, Washington The International Bank for Reconstruction and Development/The World Bank.

Zalewski A. (2000), Ekonomika rozwoju lokalnego (wybrane zagadnienia), [w:] M. Majchrzak (red.), Samorząd terytorialny a rozwój lokalny. Monografie i opracowania, nr 483, SGH, Warszawa, s. 9-37.

\title{
SPATIAL INFORMATION SYSTEMS - A PARTICIPATORY POLICY TOOL FOR LOCAL DEVELOPMENT
}

\author{
(Summary)
}

Local development policy consists of many sub-policies that allow for proper management of a commune. Tools that support the process of management and decision-making in local government units are land information systems. Their use is also possible in the development of a participatory model of a commune. 
The chapter presents the essence of local development policy and identifies the tools used in the process of its operation. Particular emphasis is put on the use of land information systems, which due to their use in communes may be an essential element of support for the implementation of territorial unit tasks. They are also a tool supporting the accomplishment of the concept of good governance in the activities of local authorities. The chapter presents good practices in the scope of use of land information systems in collecting data and supporting decision-making processes with the use of these tools. An important element of the participatory decision-making is the SoftGIS method identified as one of the best functioning methods in Scandinavian conditions, which is also used in Poland. In the chapter, data from the research carried out in the scope of good governance, showing the level of civic engagement in co-government, has been used.

Key words: local development policy, land information systems, good governance, local development, sectoral policies, social participation. 